INTERNATIONAL JOURNAL OF MULTIDisciplinARY RESEARCH AND ANALYSis

ISSN(print): 2643-9840, ISSN(online): 2643-9875

Volume 04 Issue 05 May 2021

DOI: $10.47191 /$ ijmra/v4-i5-12, Impact Factor: 6.072

Page No.- 580-586

\title{
An Empirical Analysis on Determinants of Accounting Internal Control Effectiveness: Evidence from Emerging Market
}

\author{
Dr. Hanh Hong HA \\ Lecturer, School of Accounting and Auditing, National Economics University, Vietnam
}

ABSTRACT : Prior research mentioned internal control as a useful management alternative to improve enterprises' operation performance and information quality. According to Trenery (2013) internal control can be fundamentally divided into two functions of operating and accounting internal control. The paper aims to identify the determinants of accounting internal control effectiveness that are addressed in existing literature review. Primary data was collected from samples of 109 members of board of directors and chief accountants in Vietnam by direct interview and email survey. The data was analyzed using exploratory factor analysis of SPSS software to illustrate the potential factors of accounting internal control effectiveness. The result shows that there are several determinants of accounting internal control effectiveness such as: good financial ratio, efficient resources deployed, errors found in the financial reports that are convergent into three specific groups of factors, namely: effectiveness and efficiency of accounting activities, reliability of financial reporting and compliance with law and accounting regulations. Based on the research findings, some suggestions are given to enterprises in Vietnam and other emerging markets to improve the effectiveness of accounting internal control.

KEYWORDS: internal control, accounting internal control effectiveness

JEL code: M31, M10

\section{INTRODUCTION}

Competitive markets and unsustainable environments such as Covid-19 disease, climate changes, diversity of customer needs and so on are external factors of firms' doing businesses have rigorously changed. Internal factors of the firms' businesses practices including organizational vision, top management support, resource readiness, corporate strategies, operational techniques, and employee competency have enhanced their success, survival and sustainability (Valtakoski, 2017). In recent years, the role of internal control within an enterprise has been increasingly stated both in academic research as well as in practice.

Currently, Vietnam has successfully contained the Covid-19 pandemic with positive economic growth. The Ministry of Planning and Investment (2020) expect Vietnam will increase its GDP by 4.6 percent and export to the EU by 42.7 percent in 2025 . These factors have helped make Vietnam to be a highly effective alternative for relocation in Southeast Asia. Investors remain upbeat on Vietnam's growth trajectory with highly continued interest in Vietnam markets. Despite of the fact of prospective future with potential opportunities, Vietnam economy exposes various weaknesses and deficiencies such as high debt ratio and weak supporting industries. According to The Ministry of Planning and Investment (2020) the economy weaknesses include shortcomings in business climate, led by concerns surrounding data transparency and corruption perceptions. Transparency is one feature of high quality information namely accuracy, integrity, consistency, completeness, validity, timeliness and accessibility (Laudon and Laudon, 2012). In order to actively change in adoption to sustainably develop and to eliminate the weaknesses, Vietnam enterprises need enhance its performance, operation and control (Valtakoski, 2017). In addition, an entity need to improve the relationship among parts to improve the quality of the understanding of the managers to see the changes that occur both inside and outside the organization, so that the top managers will quickly and accurately respond (Edward, 2011).

According to COSO (2013) internal controls are a crucial component of an enterprise's governance system and ability to manage risk, and it is fundamental to supporting the achievement of an enterprise's objectives and creating, enhancing, and protecting stakeholder value. Sound internal controls help ensure that transactions are properly authorized, that supporting IT systems are well-managed, and that the information contained in financial reports is reliable. Internal control is a process, affected by an entity's board of directors, management and other personnel, designed to provide reasonable assurance regarding the 


\section{An Empirical Analysis on Determinants of Accounting Internal Control Effectiveness: Evidence from Emerging Market}

achievement of objectives. To identify determinants of accounting internal control effectiveness, research method is moving beyond traditional methods of analyzing five internal control's components. The effectiveness of accounting internal control has been becoming a focused research topic of several academic researchers (Al - Hiyari et al, 2013; Fardinal, 2013).

This paper focuses on internal control, particularly regarding the accounting control but not the operating control function, as a strategic mechanism tool of their operations that can provide qualified accounting information. Firms with effective accounting control system can benefit from useful accounting information and therefore determine their outcomes in short-term, namely competitive advantage, performance and success in long-term operations and future practice.

Theoretically, literature review addresses several characteristics of an effective accounting internal control system, however, there is a lack of comprehensive study on the issue, especially in emerging countries like Vietnam where has some unique features such as low level of internal control application and manual accounting control activities. Even though several researches were conducted in other developing countries such as Thailand, Malaysia, Nigeria and so on there is no evidence to prove the case in Vietnam. Implementing this research in the context of Vietnam is necessary to find out a solution for urgent issue as well as to build up literature review on internal control.

\section{LITERATURE REVIEW}

\subsection{Literature review on internal control effectiveness}

Internal control system is considered as a valuable management tool of firms that can help prevent loss and misappropriation of resources and assets, comply with laws and regulations, ensure a reporting of reliable financial information, and achieve performance targets (Paletta and Alimehmeti, 2018). It is a set of instructions, processes, procedures, systems, and structures which firms ensure that resources are obtained and used effectively and efficiently in accomplishment and achievement of their strategic objectives and organizational affectivity and performance (Suarez, 2017).

Although several definitions of internal control have been illustrated in literature review, the Committee of Sponsoring Organization's framework COSO (2013) is widely used as references by many authors and researchers as a standardized framework. According to COSO (2013) internal control is a component of risk-management processes and a key element of enterprise governance. An effective internal control system is one of the best defenses against business failure. Internal controls are activities and actions that are designed to protect an enterprise and its related business units from loss or misuse of its assets. Sound internal controls help ensure that transactions are properly authorized, that supporting information technology systems are well-managed, and that the information contained in financial reports is reliable (COSO, 2013).

The literature seems generally to identify some typical types of internal control. Internal control takes different natures, addressing various perspectives - operational, administrative, accounting and political (Davidson et al, 2005; Carvalho et al., 2013; Bimo et al., 2019):

- Operational internal control: is the verification of the way a municipality's expenditure and revenue are forecasted and executed, both in terms of legality - financial regularity - and in terms of efficiency, effectiveness, and economy; it might also include the verification of the bases for presentation of financial statements.

- Administrative internal control: is a hierarchical control of the procedures and records related to decision making processes, plans, policies, and objectives established by those in charged with corporate governance; it aims at guaranteeing the legitimacy, regularity, and fairness of the administrative action.

- Accounting internal control: is the control of procedures aimed at guaranteeing reliability in the accounting records and accuracy in the preparation of accounting information, associated with compliance with accounting rules; making easier the review of the authorized financing operations; and asset safeguarding.

- Political internal control: is the control exerted by the municipal council over the executives, regarding the general management of the local authority.

In terms of accounting information system, accounting internal controls is considered to be an influenced factor rather than other components. It comprises of operational or administrative and accounting internal controls. In this research, accounting control function is one component of internal control system and it is proposed as a key determinant of driving and explaining firms' accounting information quality, value creation and corporate success. Interestingly, accounting control is defined as a control of procedures aimed at guaranteeing reliability in accounting records and accuracy in preparation of accounting information, associated with compliance with accounting rules, making easier reviews of authorized financial operations and safeguarding firms' assets and resources directly and indirectly (Nogueira and Jorge, 2017). It is a main instrument for credibility and validation of 


\section{An Empirical Analysis on Determinants of Accounting Internal Control Effectiveness: Evidence from Emerging Market}

firms' financial information. Firms with effective accounting control function can have beneficial and useful information to facilitate and support managerial decision making consistent with their strategic goals. Accordingly, accounting controls can ensure accuracy and integrity of accounting records and reliability of information produced, safeguard their assets from loss by fraud or unintentional errors, promote planning, operational and decision-making effectiveness, and encourage adherence to adopted policies in those business responsibilities.

\subsection{Literature review on determinants of accounting internal control effectiveness}

There have been no commonly accepted measurements techniques for internal control effectiveness (Ramos, 2004), however, in order to measure the effectiveness of accounting internal control, literature addressed some perspective approach.

Ogneva et al (2007), Beneish et al (2008), proposed that a firm without material weaknesses has an effective accounting internal control. In addition, a firm that reports material weaknesses reduces the effectiveness of internal control. On the other hands, several researches such as Dechow et al (2010), Rice and Weber (2012) have an opposite view when assessing accounting internal control effectiveness. They argued that measuring the effectiveness of internal control requires adopting a broader perspective than is possible by relying on material weaknesses. Even if a firm has not reported material weaknesses on annual accounting reports, there is a possibility that it's accounting internal control varies in effectiveness, and may be at any level between low and high. Especially, there are many cases that local accounting standards and regulations do not compulsory require to report material weaknesses. Therefore, using material weaknesses as a proxy or accounting internal control effectiveness could not always be informative.

Some previous studies followed a point of view that the effectiveness of accounting internal control measured by the existence of the accounting internal control five elements and effective operation. Stringer and Carey (2012) evaluated accounting internal control effectiveness as follows:

- Control environment evaluation. It includes the employee's moral integrity and values, the leadership of the management level, the company's organizational structure, social environment of companies

- Risk assessment evaluation. It focuses on various risk factors in the management of accounting controls of the organization including the goal setting, risk identification, risk analysis and risk response.

- Control activities evaluation. Control activities are the core of internal control and can be divided into control activities planning and execution

- Information and communication evaluation. This element includes measurement indicators namely: Information transfer timely and accurate, Fairness and justice mechanism, Communicate smoothly, Information utilization degree

- Internal monitoring evaluation. Internal monitoring is measured by some indicators: Internal supervision can cover and monitor company daily business activities, Perfect internal control mechanism and improve the scientific, objective and submitted, internal control construction and evaluation document keeping properly

Following the perception of five components of internal control some prior studies have suggested other alternative proxies for internal control effectiveness. These include:

- the existence or costs of an internal audit function (Goodwin-Steward et al, 2006);

- the existence of an audit committee (Davidson et al, 2005) or

- the implementation of enhanced financial audits (Kinney and Shepardson, 2011)

When measuring the effectiveness of accounting internal control, some modern researchers focus on the underlying concept that it could be measured by the extent the accounting system achieves three objectives of effectiveness and efficiency of operations, reliability of financial reporting and compliance with applicable laws and regulations.

Gable et al (2003) presented the effectiveness of internal control by measuring three constraints as following:

- Effectiveness and efficiency of operations (EEO) which pertains to the effectiveness and efficiency of operations by enabling firms to respond appropriately to risks, and accomplish performance and profitability goals and safeguard assets.

- Reliability on financial reporting (REF) which covers the process of preparation financial statements.

- Compliance with law and regulations (LAW) which specifies adherence to the laws and regulations the organization is subject to.

Ramos (2014) allocated the extent of internal control effectiveness into five levels basing on internal control reliability model.

- Reliability level 1: Initial. Control objectives are not well defined or consistently understood throughout the organization. Policies and procedures are generally undocumented. As a result, control policies and procedures generally are not linked 


\section{An Empirical Analysis on Determinants of Accounting Internal Control Effectiveness: Evidence from Emerging Market}

to objectives or are not consistent with each other. The effectiveness of an initial internal control depends almost exclusively on the skills, competence and ethical values of the individuals.

- Reliability level 2: Informal. Common, intuitive control practices begin to emerge but documentation is sporadic and inconsistent. Informal communication of information about internal control matters exists but the lack of formal communication methods, together with a lack of training. Management is aware of the needs for controls but still views internal control as separate forms.

- Reliability level 3: Systematic. Management understands that internal control is an integral part of the company's business and that maintaining effective system is one of their primary responsibilities. Documentation of control policies and procedures is comprehensive and consistent. With more formal, standardized controls in place, the system is more reliable, as it overall effectiveness depends more on the organization and less on the capabilities of the individual.

- Reliability level 4: Integrated. Management understands the full requirements for maintaining an effective system of internal control. Controls are fully integrated into the strategic an operational aspects of the business. The company begins a formal process for the regular monitoring of the effectiveness of internal control.

- Reliability level 5: Optimized. Management commits to a process of continuous improvement of controls. The entity uses automation and sophisticated tools and techniques to monitor controls on a real time basis and make changed as needed.

Al-Hiyari et al (2013) measured the effectiveness of accounting internal control system basing on some main features:

- Accounting information is reliable to implement internal control

- Monthly review is prepared periodically and constantly

- Follow the procedures of accounting compliance to make sure that the balances are correct

- Internal Accounting Standards are adopted the preparation of financial statements

- The accounting system can implement the procedures of monitoring and tracking accounting operations

- Implementing control procedures to ensure correct treatment, accounting and settlement

- Analytical statements are prepared to verify the correctness and conformity of the balances

- Ensure that accounting processes are consistent with financial legislations

- The implementation of the periodic documentary audit

- The technical financial control procedures are implemented in a systematic and planned manner

- Carry out inventories of the fund and various assets to ensure their existence

This study emphasize the measurement of the effectiveness of accounting internal control on the extent that the system could achieve its fundamental objectives.

\section{RESEARCH METHODOLOGY}

The purpose of the research is to refine and validate attributes suggested in literature review and prior research Al-Hiyari et al (2013) Gable et al (2003). In addition, understanding the relative perceived important of factors and the attributes provides an opportunity to focus on critical concern and illustrates recommendations. Starting with various research results on accounting internal control effectiveness, research then based on prior surveys and other research where accounting internal control effectiveness attributes have been identified. We conducted in depth interviews with knowledgeable and experienced practitioners and academic researchers to evaluate each indicator of factors on accounting internal control effectiveness in the context of Vietnam. Finally, we present 3 factors including: effectiveness and efficiency of accounting activities, reliability of financial reporting, compliance with law and accounting regulations. The questionnaire is structured in two main parts: General information and Detail information.

The first part of personal information includes question of respondent's position, qualification, gender and number of year working. The second part includes 19 statements basing on description of each attributes of independent and dependent variables. The question requires interviewees evaluate the extent of agreement to a statement typically in relevant to 5 points of Linkert scale: (1) totally disagree, (2) disagree, (3) neutral, (4) agree, (5) totally disagree

The research conducted 2 types of data collections including direct and on survey. In order to determine the relationships between individual item and identified factors, the factor analysis is performed from samples of 109 respondents. 
An Empirical Analysis on Determinants of Accounting Internal Control Effectiveness: Evidence from Emerging Market

\section{RESULTS AND DISCUSSION}

\subsection{Cronbach's Alpha Test}

In order to assess the reliability of the scale, the Cronbach's Alpha test is performed. Cronbach Alpha is very sensitive to the number of variables in each attribute which closely related a set of items are as a group. It is considered to be a measure of scale reliability

Table 4.1 illustrates the Cronbach's Alpha test of reliability of internal control effectiveness's attributes. The result shows that the Cronbach's Alpha coefficient greater than 0.6 and the correlation coefficient of all attributes was greater than 0.3 , so the attributes of the effectiveness of internal control are considered to fit in the study.

Table 4.1. Cronbach's Alpha Test result

\begin{tabular}{|c|c|c|c|c|}
\hline & $\begin{array}{l}\text { Scale Mean } \\
\text { if Item Deleted }\end{array}$ & $\begin{array}{l}\text { Scale Variance } \\
\text { if Item Deleted }\end{array}$ & $\begin{array}{l}\text { Corrected Item- } \\
\text { Total Correlation }\end{array}$ & $\begin{array}{l}\text { Cronbach's Alpha if } \\
\text { Item Deleted }\end{array}$ \\
\hline \multicolumn{5}{|c|}{ Effectiveness and efficiency of accounting activities (EFEF) } \\
\hline \multicolumn{5}{|c|}{ Cronbach's Alpha: .674 } \\
\hline \multicolumn{5}{|c|}{ No of Items: 4} \\
\hline EFEF1 & 10.02 & 3.944 & .552 & .609 \\
\hline EFEF2 & 10.39 & 3.621 & .617 & .586 \\
\hline EFEF3 & 10.86 & 3.421 & .688 & .705 \\
\hline EFEF4 & 10.73 & 4.902 & .682 & .671 \\
\hline \multicolumn{5}{|c|}{ Reliability on Financial Reporting (RELI) } \\
\hline \multicolumn{5}{|c|}{ Cronbach's Alpha: .748 } \\
\hline \multicolumn{5}{|c|}{ No of Items: 4} \\
\hline RELI1 & 10.07 & 4.134 & .408 & .615 \\
\hline RELI2 & 9.49 & 4.730 & .423 & .732 \\
\hline RELI3 & 9.36 & 4.288 & .491 & .684 \\
\hline RELI4 & 9.75 & 4.513 & .549 & .669 \\
\hline \multicolumn{5}{|c|}{ Compliance with law and accounting regulations (LAW) } \\
\hline \multicolumn{5}{|c|}{ Cronbach's Alpha: .701 } \\
\hline \multicolumn{5}{|c|}{ No of Items: 4} \\
\hline LAW1 & 9.01 & 3.408 & .416 & .739 \\
\hline LAW2 & 9.47 & 3.787 & .549 & .642 \\
\hline LAW3 & 9.56 & 3.438 & .603 & .678 \\
\hline LAW4 & 9.15 & 3.123 & .506 & .754 \\
\hline
\end{tabular}

(Source: Analysis by the researchers from SPSS 22.0)

\subsection{Exploratory Factor Analysis}

Exploratory Factor Analysis (EFA) is applied to assess the convergent and validity of the constructs. Before conducting EFA, a test for significance the correlation matrix for the variables was obtained in order to decide whether factoring the variables is appropriate.

The table 4.2 shows the tests that indicate the suitability of the data for structure detection. KMO returns value between 0 and 1 , specifically from 0.8 to 1 indicate the sampling is adequate. High values which are close to 1.0 generally indicate that the factor analysis is useful with data.

Table 4.2. KMO and Barlett's Test Result of Accounting Internal Control Effectiveness

\begin{tabular}{|c|c|}
\hline Kaiser-Meyer-Olkin Measure of Sampling Adequacy. & .801 \\
\hline Bartlett's Test of Sphericity Approx. Chi-Square & 566.11 \\
\hline Df & 66 \\
\hline Sig. & .000 \\
\hline
\end{tabular}

(Source: Analysis by the researchers from SPSS 22.0) 


\section{An Empirical Analysis on Determinants of Accounting Internal Control Effectiveness: Evidence from Emerging Market}

\subsection{Discussion and recommendations}

Understanding the importance and benefits of establishing an effective accounting internal control for providing accounting information system quality, enterprises in Hanoi could gain more competitive advantages to recover during a current recession period.

The result identifies that there are three main determinants of accounting internal control effectiveness namely the effectiveness and efficiency of accounting activities, the reliability of financial reporting and the compliance with law and accounting regulations. The firms therefore should review the accounting procedures annually and identify the deficiencies exits within accounting process. The standardization of accounting process including organization of accounting documents, accounts and accounting books should be monitored by executive directors. The accounting internal control's best practice is the delegation or segregation of authorities and accountabilities. This function requires a set in place specific policies that will guide and shape organizational behavior at all levels of management including:

- A corporate code of conduct

- Establishment of effective risk management policies, which include the accounting internal control system and internal audit function

The methods to address the corporate code of conduct should be written simply, clearly and concisely, stating relevant minimum amounts of authority for each level of management. The documents should be reviewed regularly to ensure changing circumstances do not render them ineffective. All personnel include accounting and administrative staffs should communicate officially via meetings or in person to ensure all management levels and staffs are aware of their responsibilities. As the limitation of internal control are human elements, collusion and unusual transactions, the accounting internal control procedures should be backed up by regular supervision and review to ensure all delegations are appropriate, current and implemented. The existence of corporate code of conduct as well as planned accounting procedures are features of effective internal control, not how the message is delivered. Process staffs may be advised verbally of their duties by their supervisions; however, this method is not as reliable or efficient as written advice.

\section{CONCLUSION}

The research is conducted to provide evidences in both academic and experimental perspectives regarding the determinants of accounting internal control effectiveness. The research confirms that the effectiveness of accounting internal control is generally described by three main attributes of the effectiveness and efficiency of accounting activities, the reliability of financial reporting and the compliance with law and accounting regulations.

The research includes a relatively weak point that is the research samples. The research samples are limit to 109 companies operating in Vietnam, which is representative. However, in comparison with a large number of companies in Hanoi, it could remain not persuasive enough. In spite of the time consuming and limitation of scope, the authors expect to expand the research samples in the future. To increase the generalizability of the study, future research may collect data from typical industries such as manufacturing, construction industry, services to obtain a comparative study for testing the research relationship between different groups of industry sector and achieve more benefits and contributions of the study.

\section{REFERENCES}

1) Al-Hiyari, A., AL-Mashregy, M. H., Mat, N. K., And Alekam, J. M. (2013), "Factors that Affect AccountingInformation System Implementation and Accounting Information Quality: A Survey in University Utara Malaysia", American Journal of Economics, Vol. 3 No.1, pp. 27-31.

2) COSO (2013), Internal Control - Integrated Framework, New York.

3) Davidson, R., Goodwin-Steward, J. and Kent, P. (2005), "Internal governance structures and earnings management", Journal of Accounting and Finance, Vol. 45, pp. 241-268.

4) Edward, B. (2011), "Internal controls and the quality of financial statements in local governments - case study: Wakiso district", Research Report Submitted to Makerere University, Kampala.

5) Fadinal, A. (2013), "The quality of Accounting Information and the accounting information system through the internal control systems: A study on Ministry and state agencies of the republic of Indonesia", Research Journal of Finance and Accounting, Vol. 4 No.6, pp. 156-161.

6) Gable, G. G., Sedera, D., and Chan, T. (2008), "Re- conceptualizing Information System Success: the IS-Impact Measurement Model", Journal of the Association for Information Systems, Vol. 9 No.7, pp. 377-408. 
An Empirical Analysis on Determinants of Accounting Internal Control Effectiveness: Evidence from Emerging Market

7) Goodwin-Steward, J. and Kent, P. (2006), "The use of internal audit by Australian companies", Managerial Auditing Journal, Vol. 21 No. 1, pp. 81-101.

8) Kinney, W. and Shepardson, M. (2011), "Do control effectiveness disclosure require SOX 404(b) internal control audits? A natural experiment with small US public companies", Journal of Accounting Research, Vol. 49 No. 2, pp. 413-448.

9) Laudon, K. C. and Laudon, J. P. (2012), Management Information Systems, $12^{\text {th }}$ edition Prentice Hall.

10) Ministry of Planning and Investment (2020), 2020 Vietnamese Enterprises White Book, Statistical Publishing House.

11) Ramos, M. (2014), "Just how effective is your internal control?". The Journal of Corporate Accounting and Finance , Hoboken Vol. 15 Iss. 6, 29-33

12) Suarez, C.A., 2017, "Internal Control Systems Leading to Family Business Performance in Mexico: A Framework Analysis." Journal of International Business Research, 16(1), 1-16.

13) Trenery, A. R. (2013), Principles of Internal Control, McGraw-Hill Education Pty Ltd

14) Valtakoski, A. (2017), "Explaining Servitization Failure and Deservitization: A Knowledge-Based Perspective." Industrial Marketing Management, 60, 138-150. 